\title{
EFEKTIVITAS LEMBAR KERJA PESERTA DIDIK (LKPD)TEMATIK INTEGRATIF BERBASIS PENDIDIKAN KARAKTER PADA TEMA LINGKUNGAN SAHABAT KITA MATERI STATISTIKA UNTUK SEKOLAH DASAR KELAS V
}

\author{
Rosalia Dyah Widiya Sari ${ }^{1}$, Dewi Rahimah ${ }^{2}$, Della Maulidiya ${ }^{3}$ \\ 1,2,3 Program Studi Pendidikan Matematika JPMIPA FKIP Universitas Bengkulu \\ email : ${ }^{1}$ rosaliadyah3@gmail.com, ${ }^{2}$ rahimah_dewi@yahoo.com, ${ }^{3}$ della.maulidiya@gmail.com
}

\begin{abstract}
Abstrak
Tujuan penelitian ini adalah untuk mendeskripsikan efektifitas dari lembar kerja peserta didik (LKPD) tematik Integratif berbasis pendidikan karakter pada tema lingkungan sahabat kita untuk sekolah dasar kelas $\mathrm{v}$ materi statistika. Jenis penelitian yang digunakan adalah penelitian pengembangan (research and development) dengan prosedur formative evaluation. Tahapan penelitian ini adalah self evaluation, prototyping, dan field test. Subyek pada penelitian ini peserta didik kelas V SD Negeri 1 Kota Bengkulu pada semester genap tahun ajaran 2016/2017. Instrumen yang digunakan: 1) lembar aktivitas peserta didik, 2) lembar aktivitas guru, 3) lembar respon peserta didik, 4) tes hasil belajar. Hasil penelitian menunjukan bahwa LKPD yang dikembangkan termasuk dalam kategori sangat efektif.
\end{abstract}

kata kunci: penelitian pengembangan, lembar kerja peserta didik (LKPD), tematik integratif, pendidikan karakter

\begin{abstract}
The research aimed to describe effectiveness from students' worksheet (LKPD) Thematic Integrative based character on the theme Environment of Our Companion For student's Grade V SD statistic material. The research type is research and development with procedure formative evaluation. The stages of this research are self evaluation, prototyping, and field test. Subjects in this research students grade V SD Negeri 1 kota Bengkulu in second semester of Academic Year 2016/2017. The Instruments used 1) activity sheet of learners, 2) activity sheet of teacher, 3) student response sheet, and 4) test result of learning. The results showed that LKPD developed included in the category very effective.
\end{abstract}

keywords: research development, students' worksheet, thematic integrative, character education

\section{PENDAHULUAN}

Sejak ditetapkan kurikulum 2013 pembelajaran di SD/MI menggunakan pembelajaran tematik integratif. Menurut Rusman (2014:254) pembelajaran tematik adalah salah satu model pembelajaran terpadu yang memungkinkan siswa, baik secara individu maupun kelompok, aktif menggali dan menemukan konsep serta prinsip - prinsip keilmuan secara holistik, bermakna dan autentik. Diungkapkan oleh Prastowo (2013:223) pembelajaran tematik integratif merupakan pendekatan pembelajaran yang mengintegrasikan berbagai kompetensi dari berbagai mata pelajaran kedalam suatu tema. Berdasarkan definisi diatas dapat disimpulkan bahwa pembelajaran tematik integratif adalah bagian dari pembelajaran terpadu yang menggabungkan beberapa kompetensi dasar dari berbagai mata pelajaran kedalam suatu tema. Tujuannya agar pembelajaran dapat lebih mudah dan bermakna karena dikaitkan dengan kehidupan nyata peserta didik. 
Menurut Sukayati dalam Prastowo (2013:140) tujuan pembelajaran tematik adalah meningkatkan pemahaman konsep yang dipelajari secara lebih bermakna, mengembangkan keterampilan menemukan, mengolah, dan memanfaatkan informasi, menumbuh kembangkan sikap positif, kebiasaan baik, dan nilai - nilai luhur yang diperlukan dalam kehidupan, menumbuh kembangkan keterampilan sosial seperti kerja sama, toleransi, serta menghargai pendapat orang lain, meningkatkan gairah dalam belajar, dan memilih kegiatan yang sesuai dengan minat dan kebutuhan peserta didik.

Pembelajaran tematik integratif memiliki beberapa keunggulan dan manfaat dalam pelaksanaaan pembelajaran seperti diungkapkan oleh Kadir \& Hanun (2014:26) keunggulan dan manfaat yang pertama adalah pembelajaran tematik dapat mengurangi overlapping antara berbagai mata pelajaran, karena mata pelajaran disajikan dalam satu unit. Kedua, pembelajaran tematik dapat menghemat waktu, karena pembelajaran tematik dilaksanakan secara terpadu antara beberapa mata pelajaran. Keunggulan dan manfaat pembelajaran tematik selanjutnya adalah peserta didik mampu melihat hubungan yang bermakna karena isi / materi pembelajaran lebih berperan sebagai sarana atau alat, bukan tujuan akhir. Pembelajaran menjadi holistik dan menyeluruh akumulasi pengetahuan dan pengalaman peserta didik tidak tersegmentasi pada disiplin ilmu atau mata pelajaran tertentu, sehingga peserta didik memperoleh pengertian mengenai proses dan materi yang saling berkaitan satu sama lain. Keunggulan dan manfaat pembelajaran tematik yang terakhir adalah adanya keterkaitan antara satu mata pelajaran dengan mata pelajaran lain dapat menguatkan konsep yang dimiliki oleh peserta didik, karena didukung dengan pandangan dari berbagai prespektif. Dengan demikian terdapat enam keunggulan dan manfaat yang diperoleh melalui pembelajaran tematik.

Penerapan kurikulum 2013 menekankan adanya pendidikan karakter dalam kegiatan pembelajaran. Menurut Musfiroh dalam Sulistiyowati (2012:20) karakter mengacu pada serangkaian sikap, perilaku, motivasi dan keterampilan. Philips dalam Muslich (2011:70) berpendapat bahwa karakter adalah kumpulan tata nilai menuju pada suatu sistem, yang melandasi pemikiran, sikap, dan perilaku yang ditampilkan. Jadi, dapat disimpulkan bahwa karakter merupakan cara berpikir yang berpedoman pada sikap, perilaku, motivasi serta keterampilan yang menjadi ciri khas setiap individu.

Muslich (2011:35) mengungkapkan bahwa tujuan pendidikan karakter adalah untuk meningkatkan mutu dan hasil pendidikan yang mengarah pada pencapaian pembentukan karakter dan akhlak mulia peserta didik secara utuh terpadu dan seimbang. Damayanti (2014:12) mengungkapkan bahwa tujuan pendidikan karakter adalah menciptakan generasi penerus yang memiliki dasar pribadi yang baik, dalam pengetahuan (cognitive), perasaan (feeling), dan tindakan (action). Dengan demikian dapat disimpulkan bahwa dengan adanya pendidikan karakter diharapkan peserta didik tidak hanya cerdas secara intelektual, tetapi juga secara emosi dan spritual. Pendidikan karakter sangat penting untuk membangun kepribadian oleh sebab itu pembentukan karakter perlu diwujudkan melalui pembelajaran disekolah.

Pembelajaran di sekolah harus sesuai dengan kurikulum 2013 sehingga perlu diterapkan pembelajaran tematik integratif dan untuk menumbuhkan karakter yang baik pada diri peserta didik perlu adanya pengintegrasian pendidikan karakter melalui kegiatan pembelajaran. Bahan ajar yang dapat dikembangkan dan mendukung implementasi dari pembelajaran tematik integratif berbasis pendidikan karakter pada kurikulum 2013 adalah Lembar kerja Peserta Didik (LKPD) tematik integratif berbasis pendidikan karakter. Diungkapkan oleh Kurniasih \& Berlin (2014:111), pengabungan pelajaran ini akan menguatkan karakter siswa karena terdapat penekanan pendidikan karakter yang lebih kuat. 
Berdasarkan instruksi Presiden (Inpres) nomor 1 tahun 2010 tentang percepatan pelaksanaan prioritas pembangunaan nasional, presiden menginstruksikan bahwa terdapat 18 nilai karakter yang harus ditanamkan kepada peserta didik yaitu: religius, jujur, toleransi, disiplin, kerja keras, kreatif, mandiri, demokratis, rasa ingin tahu, semangat kebangsaan, cinta tanah air, menghargai prestasi, bersahabat/ komunikatif, cinta damai, gemar membaca, peduli lingkungan, peduli sosial, tanggungjawab. Pemilihan nilai-nilai karakter yang akan digunakan disesuaikan dengan kepentingan dan kondisi satuan pendidikan masing-masing. Karakter yang dipilih pada pengembangan LKPD ini, adalah jujur, kreatif, rasa ingin tahu, komunikatif, gemar membaca dan peduli lingkungan.

Pada kurikulum 2013 LKS (Lembar kerjasiswa) mengalami perubahan penyebutan menjadi LKPD (Lembar Kerja Peserta Didik). Menurut Trianto (2011:222) LKPD adalah panduan yang digunakan siswa untuk melakukan kegiatan penyelidikan atau pemecahan masalah. LKS dan LKPD memiliki pengertian yang sama. Karena penelitian ini dilakukan di sekolah yang menerapkan kurikulum 2013, maka penulis menyebut LKS ini dengan LKPD.

Penelitian ini mengembangkan LKPD tematik integratif berbasis pendidikan karakter untuk memenuhi standar pembelajaran pada kurikulum 2013. Batasan dalam penelitian ini adalah tema yang diambil pada LKPD adalah tema 9 yaitu lingkungan sahabat kita sub tema 1 manusia dan lingkungan untuk kelas v. Materi matematika yang dibahas dalam LKPD ini adalah statistika. Artikel ini hanya membahas mengenai deskripsi dari uji efektifitas dengan menggunakan metode formative evaluation.

\section{METODE}

Subjek pada penelitian ini adalah peserta didik kelas V A SD Negeri 1 Kota Bengkulu Tahun Ajaran 2016/2017. Menurut Tessmer (1993) tahap formative evaluation meliputi self evaluation, prototyping (expert reviews, one-to- one, dan small group), dan field test. Berikut ini penjelasan tahap formatif evaluation.

1. Self Evaluation

Tabel 1. Tahap self evaluation

\begin{tabular}{|c|c|}
\hline $\begin{array}{l}\text { Tahap self } \\
\text { evaluation }\end{array}$ & Hasil Yang diharapkan \\
\hline a.Analisis & $\begin{array}{l}\text { Pada tahap ini peneliti } \\
\text { melakukan analisis peserta } \\
\text { didik, kurikulum dan perangkat } \\
\text { atau bahan pembelajaran yang } \\
\text { digunakan disekolah. Analisis } \\
\text { peserta didik bertujuan untuk } \\
\text { mengetahui karakteristik } \\
\text { peserta didik yang meliputi } \\
\text { kemampuan akademis, } \\
\text { kognitif, dan cara belajar } \\
\text { peserta didik. Analisis } \\
\text { kurikulum bertujuan untuk } \\
\text { mengetahui kurikulum yang } \\
\text { digunakan di sekolah. Analisis } \\
\text { perangkat atau bahan ajar } \\
\text { bertujuan untuk mengetahui } \\
\text { perangkat dan bahan ajar yang } \\
\text { digunakan oleh guru disekolah. } \\
\text { Analisis dilakukan dengan cara } \\
\text { pengamatan dan wawancara } \\
\text { dengan guru yang } \\
\text { bersangkutan. } \\
\text { Informasi yang diperoleh } \\
\text { setelah melakukan analisis } \\
\text { adalah kurikulum yang } \\
\text { digunakan di SD negeri } 1 \text { kota } \\
\text { bengkulu adalah kurikulum } \\
\text { 2013, dengan menggunakan } \\
\text { pembelajaran tematik } \\
\text { integratif. Peserta didik berada } \\
\text { pada tahap operasional konkret } \\
\text { sehingga kegiatan } \\
\text { pembelajaran dihubungkan } \\
\text { dengan hal - hal nyata yang } \\
\text { ada disekitar peserta didik. } \\
\text { Materi matematika yang } \\
\text { dipelajari pada tema } 9 \text { adalah } \\
\text { statistika }\end{array}$ \\
\hline b. Desain & $\begin{array}{llr}\text { Berdasarkan } & \text { analisis } \\
\text { kebutuhan, } & \text { produk } \\
\text { dikembangkan } & \text { pada penelitian } \\
\end{array}$ \\
\hline
\end{tabular}




\begin{tabular}{|c|c|}
\hline Tahap self & Hasil Yang diharapkan \\
\hline & $\begin{array}{l}\text { adalah LKPD. Desain LKPD } \\
\text { disesuaikan dengan } \\
\text { pembelajaran tematik integratif } \\
\text { berbasis pendidikan karakter. } \\
\text { LKPD yang dirancang memuat } \\
\text { empat karakteristik bahan ajar } \\
\text { tematik integratif yaitu aktif, } \\
\text { menyenangkan, holistik dan } \\
\text { autentik dilengkapi dengan } \\
\text { pendidikan karakter. } \\
\text { Pemberian judul pada LKPD } \\
\text { disesuaikan dengan tema dan } \\
\text { isi pembelajaran. Pada tahap } \\
\text { ini peneliti merancang desain } \\
\text { dan menghasilkan LKPD. } \\
\text { LKPD yang dihasilkan disebut } \\
\text { dengan prototipe } 1 .\end{array}$ \\
\hline
\end{tabular}

2. Prototyping

Tabel 2. tahap prototyping

\begin{tabular}{|l|l|}
\hline $\begin{array}{c}\text { Tahap } \\
\text { prototyping }\end{array}$ & \multicolumn{2}{|c|}{ Hasil Yang diharapkan } \\
\hline a. Expert & $\begin{array}{l}\text { LKPD prototipe 1 yang telah } \\
\text { dihasilkan diberikan pada } \\
\text { validator untuk ditelaah } \\
\text { materi, konstruksi dan } \\
\text { bahasa. Kritik dan saran yang } \\
\text { diberikan validator dijadikan } \\
\text { bahan untuk merevisi LKPD. } \\
\text { Tahap expert review akan } \\
\text { menghasilkan LKPD yang } \\
\text { valid sehingga dapat } \\
\text { digunakan pada uji coba } \\
\text { selanjutnya. }\end{array}$ \\
\hline $\begin{array}{l}\text { one-to- } \\
\text { one }\end{array}$ & $\begin{array}{l}\text { Uji coba one - to - one } \\
\text { dilakukan bersamaan dengan } \\
\text { expert review. Pada tahap } \\
\text { expert review dan one-to-one } \\
\text { akan menghasilkan LKPD } \\
\text { yang disebut dengan prototipe } \\
\text { II. Pada tahap one -to-one ini } \\
\text { diujikan pada dua orang } \\
\text { peserta didik. }\end{array}$ \\
\hline
\end{tabular}

\begin{tabular}{|l|lr|}
\hline c. Small & \multicolumn{3}{|c|}{ Uji small group atau uji } \\
group & kepraktisan. Data yang \\
& diperoleh pada uji small \\
group digunakan sebagai \\
pedoman untuk merevisi \\
LKPD sehingga dihasilkan \\
LKPD dengan kriteria praktis \\
dan dapat digunakan pada uji \\
efektifitas. Hasil revisi pada \\
uji kepraktisan menghasilkan \\
LKPD prototipe III. Uji Small \\
group dilakukan pada 8 orang \\
peserta didik.
\end{tabular}

\section{Field Test}

LKPD prototipe III yang telah memenuhi kriteria valid dan praktis diujicobakan pada tahap field test. Field test merupakan uji coba lapangan dengan situasi nyata. Uji field test dilakukan pada 24 orang peserta didik kelas VA SD Negeri 1 kota bengkulu.

Instrumen yang digunakan untuk menghasilkan LKPD yang efektif adalah: lembar aktivitas guru, lembar aktivitas peserta didik, lembar respon peserta didik, dan lembar tes hasil belajar. Data yang diperoleh dari keempat instrumen tersebut diolah dan dianalisis untuk mengetahui tingkat keefektifan LKPD yang dikembangkan.

Teknik analisis data yang digunakan pada penelitian ini mengacu pada skala linkert sebagai berikut:

a. Pengolahan data aktivitas guru

Data aktivitas guru diperoleh berdasarkan hasil pengisian angket aktivitasguruyang dilakukan oleh observer selama kegiatan pembelajaran berlangsung. Skor dan pilihan jawaban pada lembar aktivitas guru adalah sebagai berikut: 1) tidak pernah, 2) hampir tidak pernah, 3) kadang - kadang, 4) sering, 5) selalu.Kriteria yang digunakan untuk mengukur tingkat efektivitas pada aktivitas guru adalah sebagai berikut. 
Tabel 3. kriteria penilaian aktivitas guru

\begin{tabular}{|c|c|}
\hline $\begin{array}{c}\text { Interval skor } \\
\text { keefektifan }\end{array}$ & $\begin{array}{c}\text { Kategori } \\
\text { Keefektifan }\end{array}$ \\
\hline $7 \leq \bar{E}<12,6$ & Tidak Efektif \\
\hline $12,6 \leq \bar{E}<18,2$ & $\begin{array}{c}\text { Kurang } \\
\text { Efektif }\end{array}$ \\
\hline $18,2 \leq \bar{E}<23,8$ & Cukup Efektif \\
\hline $23,8 \leq \bar{E}<29,4$ & Efektif \\
\hline $29,4 \leq \bar{E}<35$ & $\begin{array}{l}\text { Sangat } \\
\text { Efektif }\end{array}$ \\
\hline
\end{tabular}

b. Pengolahan data aktivitas peserta didik Data aktivitas peserta didik diperoleh dengan cara observer melakukan pengamatan aktivitas peserta didik selama kegiatan pembelajaran berlangsung kemudian mengisi angket yang telah disediakan. Skor dan pilihan jawaban pada lembar aktivitas peserta didik adalah sebagai berikut: 1) tidak pernah, 2) jarang sekali, 3) jarang, $\quad$ 4) sering, 5) selalu. Kriteria yang digunakan untuk mengukur tingkat efektivitas pada lembar aktivitas peserta didik dapat dilihat pada tabel berikut ini.

Tabel 4.kriteria penilaian aktivitas peserta didik

\begin{tabular}{|c|c|}
\hline $\begin{array}{c}\text { Interval skor } \\
\text { keefektifan }\end{array}$ & $\begin{array}{c}\text { Kategori } \\
\text { Keefektifan }\end{array}$ \\
\hline $9 \leq \bar{E}<16,2$ & Tidak Efektif \\
\hline $16,2 \leq \bar{E}<23,4$ & $\begin{array}{c}\text { Kurang } \\
\text { Efektif }\end{array}$ \\
\hline $23,4 \leq \bar{E}<30,6$ & Cukup Efektif \\
\hline $30,6 \leq \bar{E}<37,8$ & Efektif \\
\hline $37,8 \leq \bar{E}<45$ & $\begin{array}{l}\text { Sangat } \\
\text { Efektif }\end{array}$ \\
\hline
\end{tabular}

c. Repon peserta didik

Penilaian respon peserta didik diperoleh berdasarkan hasil pengisian lembar respon peserta didik setelah kegiatan pembelajaran dengan menggunakan LKPD. Skor dan pilihan jawaban pada lembar respon adalah sebagai berikut: 1) sangat tidak setuju, 2) tidak setuju, 3) ragu - ragu, 4) setuju, 5) sangat setuju.

Untuk mengukur kriteria pada setiap aspek penilaian dapat dilihat pada tabel 5 berikut ini.
Tabel 5.Kriteria penilaian respon peserta didik

\begin{tabular}{|c|c|}
\hline $\begin{array}{c}\text { Interval skor } \\
\text { keefektifan }\end{array}$ & $\begin{array}{c}\text { Kategori } \\
\text { Keefektifan }\end{array}$ \\
\hline $12 \leq \bar{E}<16,2$ & Tidak Efektif \\
\hline $21,6 \leq \bar{E}<31,2$ & $\begin{array}{c}\text { Kurang } \\
\text { Efektif }\end{array}$ \\
\hline $31,2 \leq \bar{E}<40,8$ & Cukup Efektif \\
\hline $40,8 \leq \bar{E}<50,4$ & Efektif \\
\hline $50,4 \leq \bar{E}<60$ & $\begin{array}{l}\text { Sangat } \\
\text { Efektif }\end{array}$ \\
\hline
\end{tabular}

d. Hasil belajar

Keefektifan hasil belajar peserta didik diukur melalui $25 \%$ nilai hasil pengerjaan LKPD dan $75 \%$ nilai tes hasil belajar dan presentase ketuntasan belajar klasikal. Berdasarkan data yang diperoleh dari tes hasil belajar kemudian dihitung berapa banyak siswa yang tuntas dalam belajar dan dibandingkan dengan Kriteria Ketuntasan Minimal yang ditetapkan oleh sekolah. Presentase ketuntasan belajar klasikal dihitung dengan menggunakan rumus berikut ini :

$$
K B=\frac{\sum x}{n} \times 100 \%
$$

Keterangan :

$\mathrm{KB}=$ ketuntasan belajar klasikal, $\sum \mathrm{x}=$ banyak peserta didik yang tuntas, $\mathrm{n}$ = Banyak peserta didik yang mengikuti tes

\section{HASIL DAN PEMBAHASAN}

Berdasarkan hasil penelitian yang telah dilakukan hasil yang diperoleh pada tahap analisis adalah sebagai berikut :

a. Efektifitas LKPD berdasarkan aktivitas guru

Berdasarkan data aktivitas guru diperoleh rata - rata skor keefektifan sebesar 29,33 dengan kriteria efektif. Terdapat 7 item pernyatan yang digunakan untuk menganalisis aktivitas guru. Tujuh item tersebut adalah sebagai berikut :

1. Menyampaikan apersepsi dan motivasi. diawal pembelajaran guru memberikan apresepsi dan motivasi kepada peserta didik tujuannya adalah agar peserta didik semangat dalam kegiatan pembelajaran. Rata - rata skor yang diperoleh pada aspek 
ini adalah sebesar 30,33 dengan kriteria sangat efektif.

2. Mengajukan pertanyaan untuk meningkatkan minat dan keingintahuan peserta didik. Pada tahap ini guru menumbuhkan rasa ingin tahu peserta didik melalui pengamatan pada gambar - gambar di LKPD. Untuk ketiga LKPD aspek ini mendapat skor rata - rata 26,83 dengan kriteri efektif. Bagian LKPD yang berfungsi untuk menumbuhkan rasa ingin tahu siswa melalui pengamatan adalah bagian berikut ini.

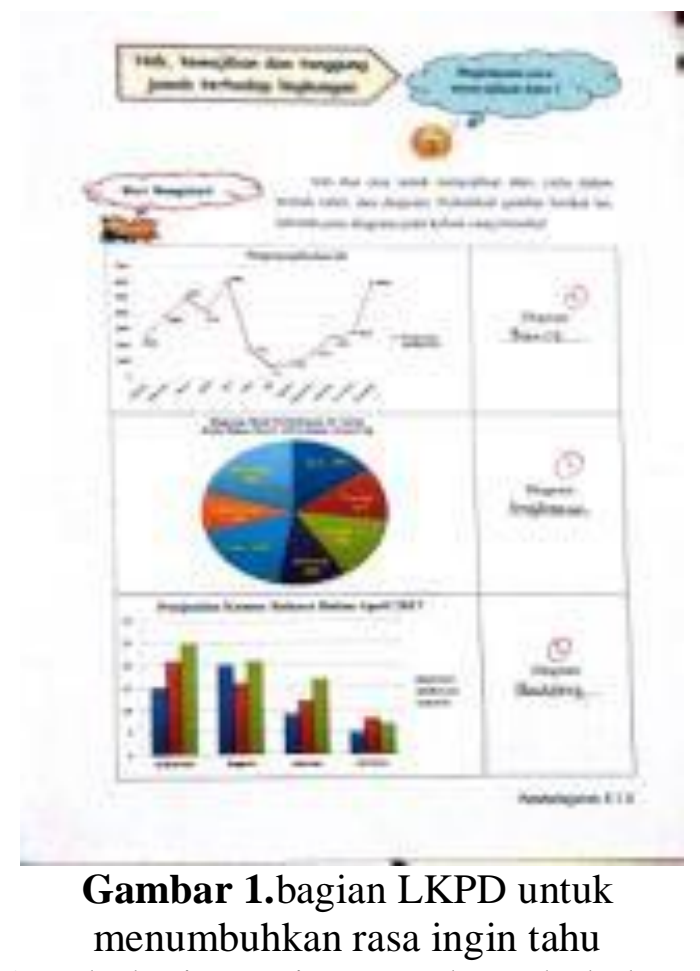

3. Aspek ketiga yaitu Membentuk kelompok untuk kegiatan pembelajaran. Guru membagi peserta didik kedalam kelompok kelompok kecil yang terdiri dari 4 orang peserta didik yang memiliki kemampuan heterogen. Aspek pengamatan ini memperoleh skor rata - rata 28,00 dengan kriteria efektif.

4. Membimbing Peserta Didik Yang Mengalami Kesulitan. Pada Aspek Pengamatan Memperoleh Skor Rata - Rata 32,67 Dengan Kriteria Sangat Efektif.

5. Memandu jalannya diskusi kelas. Aspek ini memperoleh skor rata - rata 29,17 dengan kriteria efektif.

6. Memberikan penjelasan berdasarkan hasil diskusi peserta didik. Diakhir pengerjaan LKPD guru menjelaskan jawaban yang tepat mengenai hasil diskusi peserta didik. Aspek ini memperoleh skor rata - rata 28,00 dengan kriteria efektif.

7. Memfasilitasi peserta didik untuk menilai kemampuannya dengan mengerjakan soal pada LKPD. pada aspek ini skor rata - rata yang diperoleh adalah 30,33 dengan kriteria sangat efektif. Berikut ini adalah gambar bagian LKPD yang memuat soal matematika untuk dikerjakan oleh peserta didik.
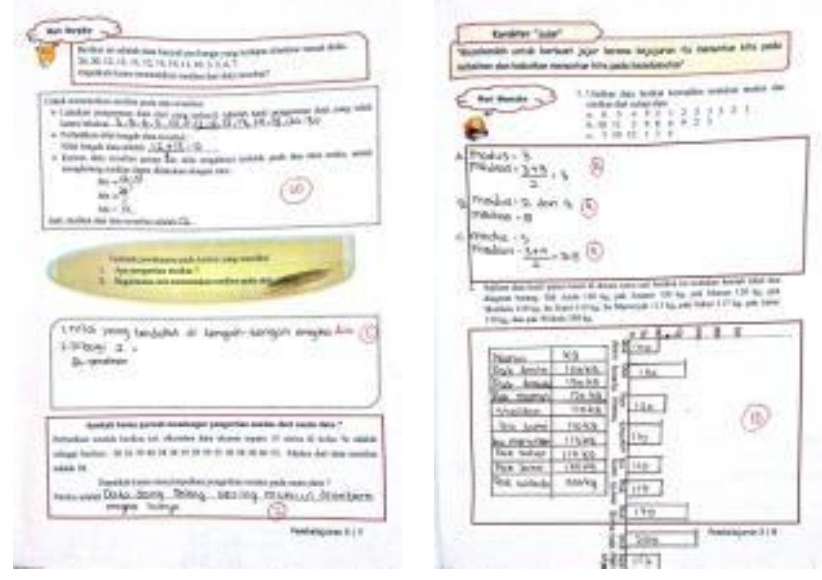

Gambar 2. soal yang dikerjakan peserta didik pada LKPD

b. Efektifitas LKPD berdasarkan aktivitas peserta didik

Berdasarkan hasil penilaian oleh observer rata - rata skor data aktivitas peserta didik adalah sebesar 38,35 dengan kriteria sangat efektif. Pada aspek penilaian aktivitas peserta didik terdapat 9 item yang diamati oleh observer. Sembilan item tersebut adalah :

1. Peserta didik merespon pertanyaan yang diberikan oleh guru. Pada aspek penilain ini rata - rata skor aktivitas yang diperoleh adalah 39,00 dengan kriteria sangat efektif.

2. Peserta didik mengajukan pertanyaan apabila mengalami kesulitan. Rata - rata skor yang diperoleh adalah sebesar 42,00 dan memperoleh kriteria sangat efektif.

3. Peserta didik melakukan kegiatan pembelajaran sesuai dengan langkah 
kegiatan yang ada di RPP dan LKPD. Aspek penilaian ini memperoleh skor rata - rata 37,50 dengan kriteria efektif.

4. Peserta didik mampu berkomunikasi dengan baik secara lisan melalui diskusi kelompok. Skor rata - rata yang diperoleh adalah sebesar 36,00 dengan kriteria efektif.

5. Peserta didik mampu berkomunikasi dengan baik secara tulisan melaui pengerjaan LKPD. Aspek ini memperoleh skor rata - rata 40,50 dengan kriteria sangat efektif. bagian LKPD yang menunjukkan karakter komunikatif dapat dilihat pada gambar berikut ini.

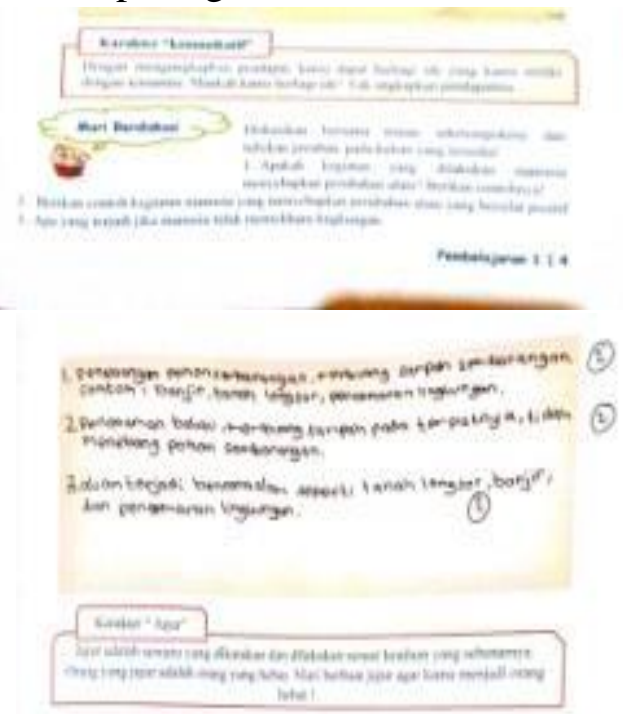

Gambar 3. karakter komunikatif pada LKPD

6. Peserta didik kreatif dalam mengemukakan ide. Skor rata - rata yang diperoleh adalah 34,50 dengan kriteria efektif. Karakter kreatif yang terdapat pada LKPD ditunjukkan pada gambar berikut ini.
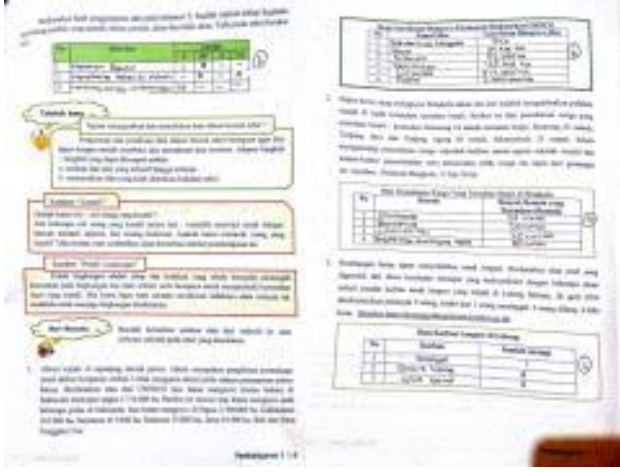

Gambar 4. karakter kreatif pada LKPD
7. Peserta didik menunjukkan rasa ingin tahu terhadap materi pelajaran. rata - rata skor yang diperoleh untuk ketiga LKPD adalah sebesar 37,50 dengan kriteria efektif.

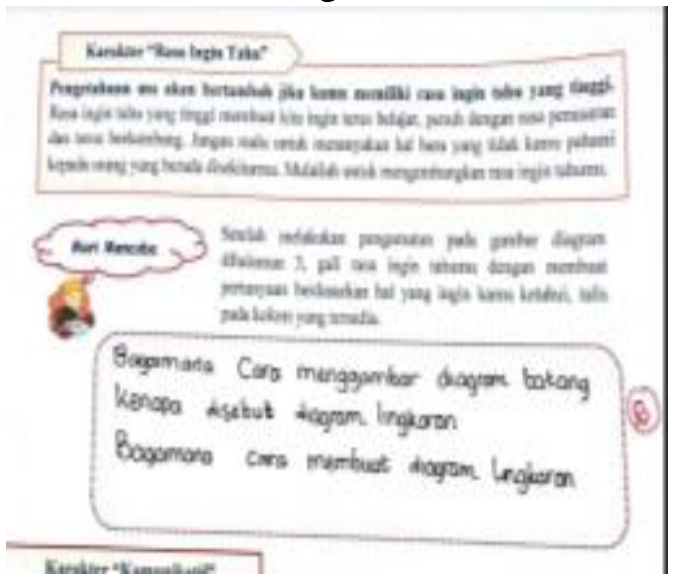

Gambar 5. karakter rasa ingin tahu pada LKPD

8. Peserta didik peduli terhadap lingkungan dengan menjaga kebersihan dan kerapian ruangan kelas saat belajar. aspek ini memperoleh skor rata - rata 40,50 dengan skor sangat efektif.

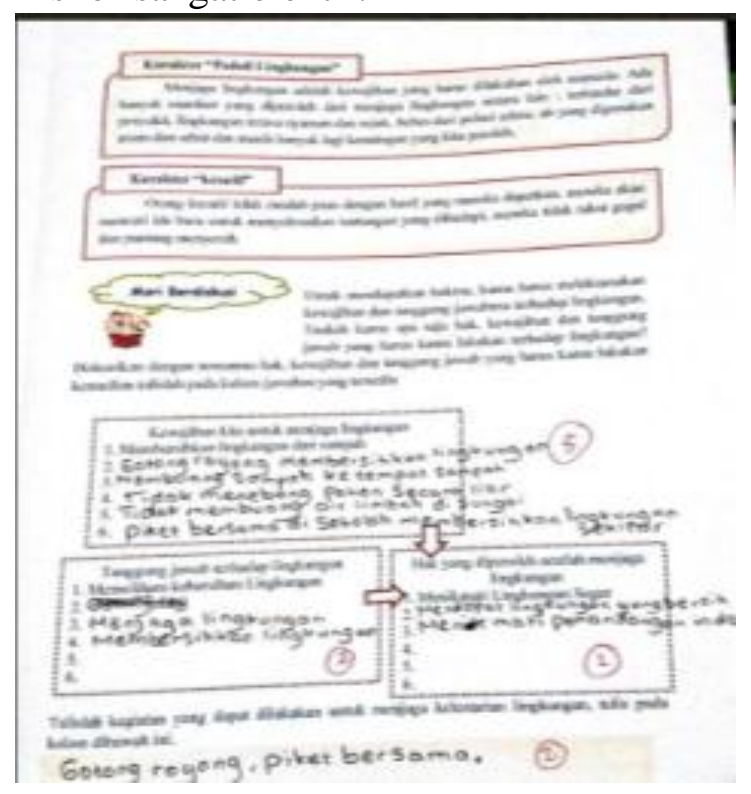

Gambar 6. peduli lingkungan pada LKPD

9. Peserta didik mampu menumbuhkan karakter gemar membaca melalui bacaan pada LKPD apek ini memperoleh skor rata -rata sebesar 37,50 dengan kriteria sangat efektif. 


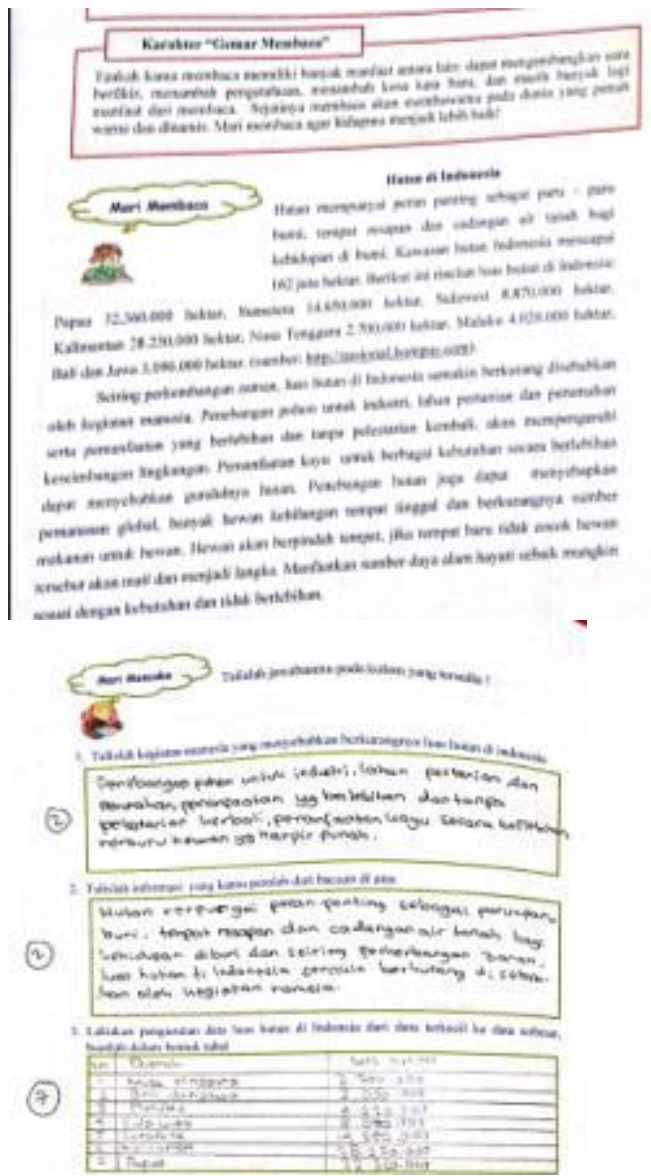

Gambar 7. karakter kreatif pada LKPD

\section{c. Efektifitas LKPD berdasarkan respon peserta didik}

Rata - rata skor respon peserta didik adalah sebesar 51,24 dengan kriteria sangat efektif. Terdapat dua belas item yang digunakan untuk mengukur penilaian ini adalah sebagai berikut :

1. Saya termotivasi untuk belajar dengan menggunakan LKPD. Rata - rata skor yang diperoleh pada item ini adalah 51,17 dan memenuhi kriteria sangat efektif.

2. Saya tertarik mempelajari materi pengolahan data dengan menggunakan LKPD. pada aspek ini rata - rata skor adalah sebesar 51,67 dengan kriteria sangat efektif.

3. Saya mudah memahami materi pengolahan data dengan menggunakan LKPD. Rata - rata skor yang diberikan adalah 50,50 dengan kriteria sangat efektif.

4. Dengan adanya kegiatan pembelajaran menggunakan LKPD saya menjadi lebih giat belajar. Aspek ini mendapat skor rata - rata sebesar 49,67 dengan kriteria efektif.
5. Saya senang belajar dengan menggunakan LKPD. Pada aspek penilaian ini rata - rata skor yang diperoleh adalah 52,00 memenuhi kriteria sangat efektif.

6. Saya menjadi anak yang jujur (tidak mencontek) dalam kegiatan pembelajaran. Aspek ini menunjukkan adanya karakter jujur yang diamati dalam kegiatan pembelajaran dan memperoleh skor rata - rata sebesar 54,33 dengan kriteria sangat efektif.

7. LKPD ini dapat menumbuhkan rasa ingin tahu. Aspek ini memperoleh skor rata - rata 48,67 dengan kriteeria

8. Setelah belajar dengan menggunakan LKPD saya dapat menyampaikan ide dengan baik aspek ini mendapat skor rata - rata sebesar 51,17 dengan kriteria sangat efektif. Aspek penilaian ini memenuhi karakter kreatif.

9. Setelah belajar dengan menggunakan LKPD saya menjadi anak yang peduli terhadap lingkungan aspek penilaian ini digunakan untuk mengukur karakter peduli lingkungan dan memperoleh skor rata - rata sebesar 52,00 dengan kriteria sangat efektif.

10. Setelah belajar dengan menggunakan LKPD saya dapat berkomunikasi dengan baik secara lisan karakter yang terlukiskan dalam penilaian ini adalah karakter komunikatif dengan skor rata -rata yang diperoleh sebesar 53,17 dengan kriteria sangat efektif.

11. Setelah belajar dengan menggunakan LKPD saya dapat berkomunikasi dengan baik secara tulisan, aspek penilaian ini digunakan untuk mengukur karakter komunikatif dan memperoleh skor rata - rata sebesar 51,83 dan memenuhi kriteria sangat efektif.

12. Setelah belajar dengan menggunakan LKPD saya menjadi anak yang gemar membaca aspek ini digunakan untuk mengukur karakter gemar membaca pada peserta didik dan memperoleh skor rata - rata 49,00 dengan kriteria sangat efektif.

\section{d. Efektifitas LKPD berdasarkan tes hasil belajar}

Tes hasil belajar yang dilakukan menunjukkan bahwa LKPD yang digunakan pada kegiatan pembelajaran sudah efektif. hal 
ini dapat dilihat dari nilai 21 orang peserta didik yang sudah berada di atas KKM dan telah memenuhi kriteria ketuntasan klasikal sebesar $87,5 \%$. gambar berikut ini menunjukkan hasil pengerjaan tes hasil belajar pesert didik.

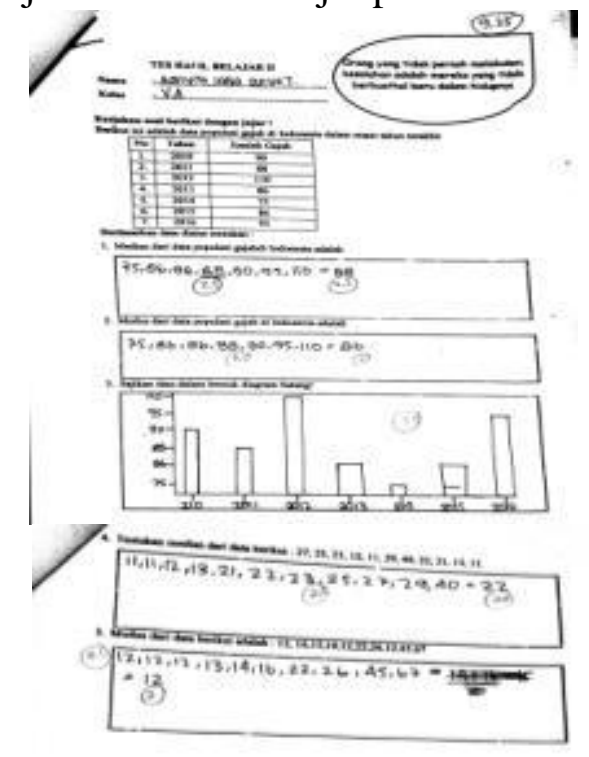

Gambar 8. tes hasil belajar

Dengan demikian LKPD yang dikembangkan memberikan dampak positif dalam kegiatan pembelajaran jika dilihat dariaktifitaspeserta didikdanguru,respon pesertadidik, sertahasil belajarpeserta didik, sehingga LKPD yang dihasilkan efektif.

\section{Kesimpulan}

Berdasarkan hasil penelitian yang dilakukan diperoleh kesimpulan tiga LKPD yang dikembangkan telah memenuhi kriteria efektif. LKPD efektif karena :

a. Aktivitas guru memenuhi kriteria efektif. Dengan skor rata - rata 29,33.

b. Aktivitas peserta didik memenuhi kriteria sangat efektif dengan skor rata - rata sebesar 38,35 .

c. Hasil belajar peserta didik kelas VA SD Negeri 1 Kota Bengkulu sangat efektif dengan skor rata - rata 51,24 dan ketuntasan belajar individu 87,5\% dengan rata - rata nilai melebihi KKM yaitu 83,73.

\section{Saran}

Berdasarkan hasil penelitian yang dilakukan, diberikan saran sebagai berikut : 1) Pengembangn LKPD tematik integratif berbasis pendidikan karakter dapat dikembangkan pada tema yang lain karena berdasarkan respon dan aktivitas peserta didik menunjukkan bahwa LKPD memberikan respon positif terhadap kegiatan belajar. Peserta didik menjadi lebih bersemangat dalam mengikuti pembelajaran dengan menggunakan LKPD. 2) Kompetensi dasar tiap pelajaran perlu diperhatikan untuk mengintegrasikan dua atau lebih mata pelajaran, sebaiknya materi pelajaran berkaitan dengan kehidupan dan lingkungan sehari hari peserta didik. 3) Untuk mengintegrasikan karakter kedalam LKPD tematik integratif ini sebaiknya karakter dideskripsikan secara jelas agar peserta didik dapat menumbuhkan karakter yang terdapat dalam pembelajaran, disertai perbuatan langsung yang menunjukkan cerminan dari karakter tersebut dan untuk penelitian lebih lanjut membahas secara rinci tahapan - tahapan diagram lingkaran, diagram batang, median, modus dam rata - rata jangan dipaparkan dalam bentuk umum. 4) Konteks penugasan pada LKPD tematik integratif berbasis pendidikan karakter sebaiknya disesuaikan dengan kegiatan yang sering dilakukan oleh peserta didik, kondisi geografis, dan materi yang disajikan kontekstual.

\section{DAFTAR PUSTAKA}

Damayanti, Deni. 2014. Panduan Implementasi Pendidikan Karakter Disekolah. Yogyakarta : Araska.

Kadir, Abdul dan Hanun Asrohah. 2014. Pembelajaran Tematik. Jakarta: Rajawali Press.

Kurinasih, Imas dan Berlin Sani. 2014. Sukses Mengimplementasikan Kurikulum 2013. Jakarta: Kata Pena.

Muslich, Masnur. 2011. Pendidikan Karakter. Jakarta : Bumi Aksara.

Prastowo, Andi. 2013. Pengembangan Bahan Ajar Tematik. Jogjakarta : Diva Press. 
Rusman, 2014. Model-Model Pembelajaran. Jakarta : Raja Grafindo Persada.

Sudjana. 2005. Metode Statistika. Bandung: Tarsito.

Sugiyono. 2016. Metode Penelitian Dan Pengembangan. Bandung: Alfabeta.

Sulistyowati, Endah. 2012. Implementasi Kurikulum Pendidikan Karakter. Yogyakarta : Pt. Citra Aji Pratama.

Tessemer, Martin. (1993). Planning And Conducting Formative Evaluations. Philadelphia: Kogan Page

Trianto. 2011. Model - Model Pembelajaran Inovatif Berorientasi Konstruktivistik. Jakarta : Prestasi Pustaka 